\title{
Termites' diversity in a protected park of the northern Sudanian savanna of Togo (West Africa)
}

\author{
Toblie Quashie Effowe', Boris Dodji Kasseney', Abdoulaye Baïla Ndiaye², \\ Bassan Banibea Sanbena', Komina Amevoin', Isabelle Adolé Glitho'
}

I Laboratoire d'Entomologie Appliquée, Département de Zoologie, Faculté des Sciences, Université de Lomé; O1BP 1515, Lomé 01, Togo 2 Laboratoire de Zoologie des Invertébrés terrestres, Institut fondamental d'Afrique noire, Université Cheikh Anta Diop; BP 206, Dakar, Senegal

Corresponding author: Boris Dodji Kasseney (borisdodji@gmail.com)

Academic editor: J.S. Pryke | Received 9 October 2020 | Accepted 25 January 2021 | Published 9 April 2021

http://zoobank.org/8AEOC79E-DDBC-43A4-ACAB-12221DD0C064

Citation: Effowe TQ, Kasseney BD, Ndiaye AB, Sanbena BB, Amevoin K, Glitho IA (2021) Termites' diversity in a protected park of the northern Sudanian savanna of Togo (West Africa). Nature Conservation 43: 79-91. https://doi. org/10.3897/natureconservation.43.59474

\begin{abstract}
Termites occur in many ecosystems throughout tropical and subtropical areas. Their distribution is driven by several factors, including landscape and some soil characteristics. This study aims to determine soil organic matter's role on termites' diversity in a shrubby savanna park. Termites were sampled across transects in 3 sites of Galangashi park (northern part of Togo). The soil in which termites were harvested was analyzed to check organic matter's influence on termites' species richness. A total of 28 termite species belonging to 14 genera and 6 subfamilies were identified. Feeding group II (all fungus-growing termites, grass feeders, and wood feeders) was the most important among the three identified groups. Nine species (with two potentially new species for sciences: Amitermes sp and Eremotermes sp) were recorded for the first time in the country. A strong correlation was found between species richness, total organic matter, and total organic carbon, suggesting the influence of soil richness on termite distribution. The occurrence of the unique member of the feeding group I, Coptotermes intermedius Silvestri, 1912, as well as the occurrence of Fulleritermes tenebricus Silvestri, 1914 (both wood-dwelling termites), was certainly due to the vegetation. The relatively higher species richness as well as the correlation between the species richness and the organic matter of shrub savanna, suggest a better conservation of this landscape.
\end{abstract}

\section{Keywords}

Organic carbon, shrub savanna, species richness, systematic

Copyright Toblie Quashie Effowe et al. This is an open access article distributed under the terms of the Creative Commons Attribution License (CC BY 4.0), which permits unrestricted use, distribution, and reproduction in any medium, provided the original author and source are credited. 


\section{Introduction}

Termites are ecosystem engineers (Jones et al. 1994) and are among the most dominant macroinvertebrates in tropical soils (Bignell and Eggleton 2000). Their nesting activities promote soil aeration, improve the absorption and storage of water in the soil, and facilitate carbon flux (Lobry de Bruyn and Conacher 1990; Sileshi et al. 2010). Worldwide, there are more than 3106 species of living and fossil termites classified into 12 families and 330 genera (Krishna et al. 2013), which are particularly abundant and diversified in tropical forest and savannas within the $10^{\circ}$ North and South latitudes from the equator (Collins 1989). Thus the majority of termite species live in tropical and subtropical ecosystems. However, they are unevenly distributed: the large equatorial forests constitute an important reservoir of termite species (Jones and Eggleton 2011). Termite species richness of these forests is estimated at more than 70 species per hectare (Eggleton 2000).

In comparison to these primary forests, agro-systems hosted fewer species because termites are very sensitive to any disturbance of their environment and are thus used as bioindicators (Viana et al. 2016). The species richness and abundance of termites are extremely affected by agricultural practices (Samb et al. 2011; Dosso et al. 2013; Kaiser et al. 2015). These and other human activities, such as mining and urbanization, are among the major causes of the loss of termite diversity (Green et al. 2005). Rainfall, as well as the type of soil, are also factors that influence the diversity of termites (Lobry de Bruyn and Conacher 1990).

Several authors (Konaté et al. 2003; Dosso et al. 2010, 2012, 2013, 2017) have conducted studies on the termite in relation to natural or processed habitats in West Africa. Moreover, it appeared that termite species richness decreases with the increase of land use (essentially for farming and agro-systems establishment). Therefore protected areas are places where more termite species could be found. In Togo, only two similar types of research have recently been carried out in the forest and teak plantation in the southern part of the country (Schyra et al. 2019) and Sudanian savannas and fallows (at different ages) in the Oti Keran park located in the northern part of the country (Schyra and Korb 2019). The park of Galangashi (our study area) is located in the north of Oti Keran park and to the best of our knowledge, no data on termites from this area are available. Because of the unprospected condition of Galangashi park (for termite species), we evaluated the diversity of termites in this protected shrubby savanna park. We also analyzed a correlation between the species richness of termites and soil total organic material.

\section{Material and methods}

\section{Study sites}

This study was carried out at Galangashie protected park located in the savanna region (Fig. 1) between $10^{\circ} 19^{\prime}-20^{\circ} 28^{\prime} \mathrm{N}$ and $0^{\circ} 14^{\prime}-0^{\circ} 27^{\prime} \mathrm{E}$ (northern part of Togo). It covers 7650 hectares, and it had been protected since its creation in September 1954. The 


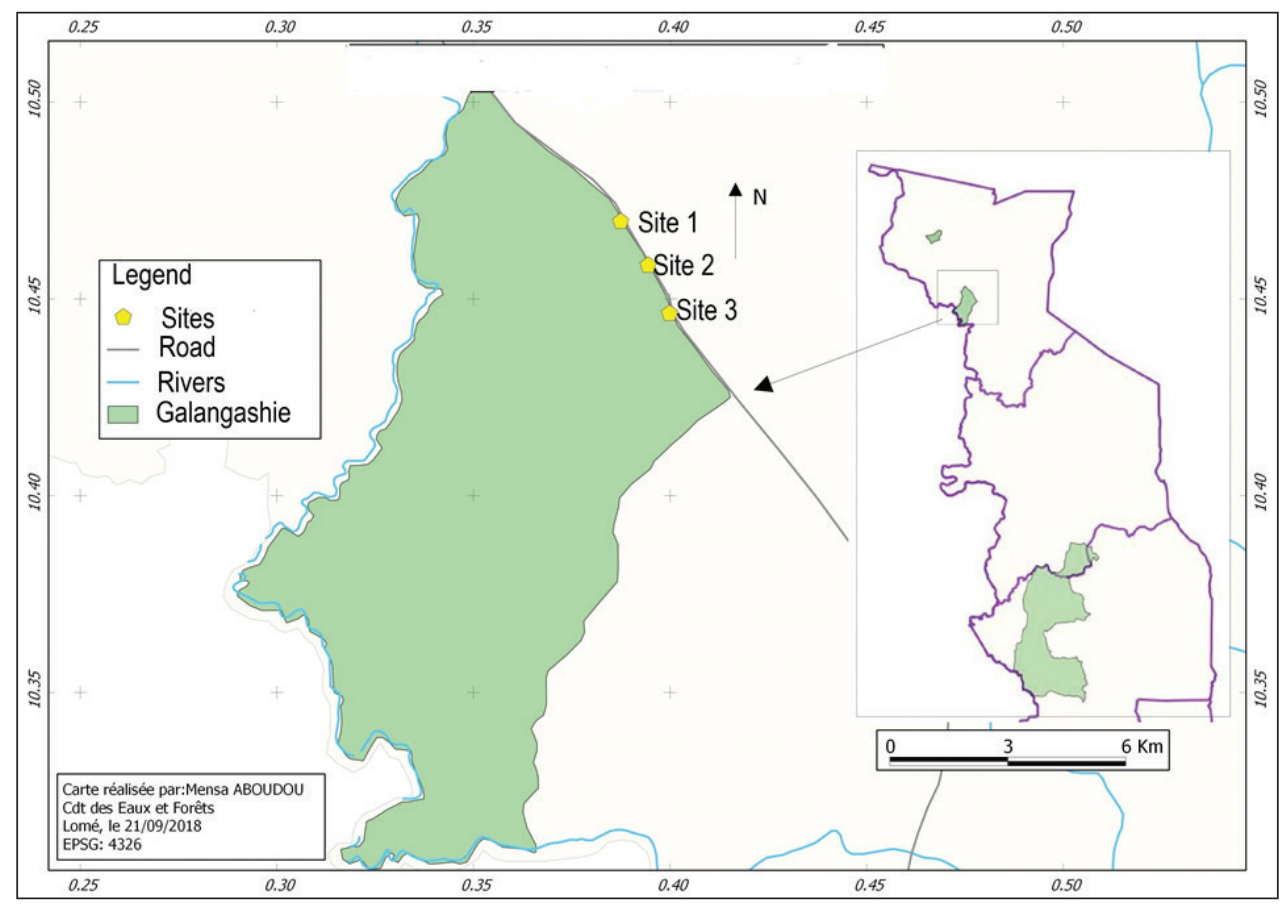

Figure I. The location of the study area Galangashie.

study area has a Sudanian tropical climate characterized by a long dry season (November to May) and a long rainy season (June to October). The mean temperatures range from $30 \pm 3{ }^{\circ} \mathrm{C}$ (during dry season) and $29 \pm 2{ }^{\circ} \mathrm{C}$ (during the rainy season) with an annual rainfall of $986 \mathrm{~mm}$. The landscape is a shrubby savanna.

\section{Sampling of termites}

Termites were sampled within the frame of belt transects. Three sets of three belt transects were laid at three sites: site $1\left(10^{\circ} 26^{\prime} 42.6^{\prime \prime}-10^{\circ} 26^{\prime} 43.4^{\prime \prime} \mathrm{N} ; 000^{\circ} 23^{\prime} 52.4^{\prime \prime}-\right.$ $\left.000^{\circ} 26^{\prime} 56.9^{\prime \prime} \mathrm{E}\right)$ site $2\left(10^{\circ} 27^{\prime} 30.8^{\prime \prime}-10^{\circ} 27^{\prime} 31.9^{\prime \prime} \mathrm{N} ; 000^{\circ} 23^{\prime} 39.5^{\prime \prime}-000^{\circ} 23^{\prime} 42.0^{\prime \prime} \mathrm{E}\right)$ and site $3\left(10^{\circ} 28^{\prime} 11.2^{\prime \prime}-10^{\circ} 28^{\prime} 10.8^{\prime \prime} \mathrm{N} ; 000^{\circ} 23^{\prime} 16.4^{\prime \prime}-000^{\circ} 23^{\prime} 16.6 " \mathrm{E}\right)$. The sets of three transects were at a distance of at least $2 \mathrm{~km}$ from each other, and two consecutive transects were separated by at least $15 \mathrm{~m}$ (Fig. 3). Each belt transect was $100 \times$ $2 \mathrm{~m}$ divided into 20 units of $5 \times 2 \mathrm{~m}$ as described by Jones and Eggleton (2000) for forest ecosystems. In our study, this standard protocol was adapted to the savanna ecosystems according to Dosso et al. 2010 and Hausberge et al. 2011. Each unit $(5 \times 2 \mathrm{~m})$ was sampled for 15 minutes, according to Schyra and Korb (2019). During this period, termites were systematically searched in their microhabitats such as litter, dead wood, trees (up to $2 \mathrm{~m}$ above ground), grasses, uprooted grass tufts and inside mounds within each sampling unit by a well-trained collector. The search time of 15 minutes was chosen instead of 30 minutes (as proposed by Jones and 


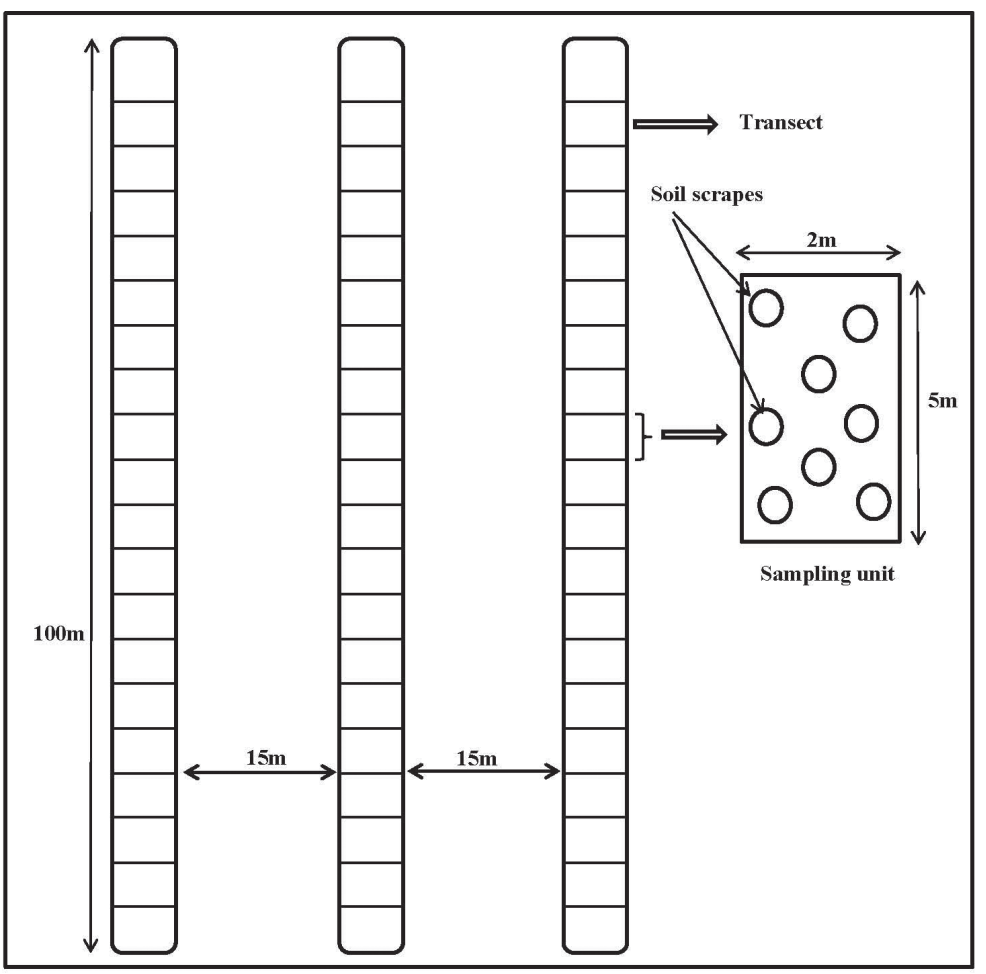

Figure 2. Scheme of transects with a sampling unit.

Eggleton 2000) because available substrates or microhabitats are lesser in savanna ecosystems than in forest ones. The length of the belt transect $(100 \mathrm{~m})$ was kept in our study, instead of $50 \mathrm{~m}$ proposed by Schyra and Korb (2019) in order to increase the sampling effort. Termites were also searched throughout eight soil scrapes of $15 \times 15 \times 10 \mathrm{~cm}$ (Fig. 2) according to Schyra and Korb (2019) within each unit. Collected termites were stored in 95\% ethanol inside labeled vials and kept in the laboratory for further processing.

\section{Termite identification}

Termite specimens were sorted and grouped into morpho-species. The identification was based on morphological characters (antenna, mandible, head, labrum, pronotum, gula) and morphometric parameters (head length and width, mandible length, pronotum width, gula width, and hind tibia length). Measurements were made using a stereomicroscope (Leica EZ4) with an integrated camera connected to a computer. Las EZ software application was used for image acquisition and mensuration. The reference works of Grassé (1937), Bouillon and Mathot (1965), Silvestri (1912), Sands (1965, 1992), and Ruelle (1970) were used for the species identification.

The voucher specimens are conserved in the entomological collection of "Laboratoire d'Entomologie Appliquée" of the University of Lomé (Togo). 
The obtained species list of this study was compared to previous studies (Anani Kotoklo et al. 2011; Kasseney et al. 2019; Schyra et al. 2019) carried on termites in Togo, in order to sort out the newly recorded species.

The identified species were classified within their corresponding feeding groups, according to Donovan et al. (2001).

\section{Evaluation of soil total organic material}

Soil samples were collected in transects in which termites were harvested. An amount of $500 \mathrm{~g}$ of soil was taken from each sampling site and kept in plastic bags. They were brought to the Laboratory of Chemistry of the University of Lomé for chemical analysis. Five grams of each soil sample (previously dried at $220^{\circ} \mathrm{C}$ ) were burned at $450{ }^{\circ} \mathrm{C}$ for 3 hours. After cooling, the percentage of mass loss generated by the calcinations constitutes the soil samples' total organic material content. The total organic carbon content was derived from the total organic matter. It was estimated to be $58 \%$ of the content of the total organic material.

\section{Data analysis}

For analysis smoothness, each set of three transects was considered as a replica. Data from each set of three transects were then pooled, and three replicates were obtained. We used the occurrence (presence or absence) and the relative abundance (the percentage of the occurrence of each single species in a sampling site) of specimen instead of a number of collected individuals because the occurrence of a single individual indicates the presence of a whole colony of termites around.

Alpha diversity indices, including the total observed richness (Sobs), Simpson index of diversity (1-D), and Shannon index, were calculated using Past 3.2 software (Hammer et al. 2001).

The test of Kendalls $\tau$ was run to examine the correlation between species richness, total organic material, and total organic carbon of the soils from each set of three transects. Because there were three sets of three transects, the sample size was 3: each set of three transects was combined to get one sample size. This test was carried out in SPPS 20 at the level of 0.01 . The coefficient of Kendalls $\tau$ test ranges from -1 (a strong negative correlation) to +1 (a strong positive correlation) with 0 value indicating no link between the examined factors.

\section{Results}

\section{Diversity}

A total of 28 species belonging to 14 genera and 6 subfamilies were identified (Table 1). Macrotermitinae subfamily not only had a higher number of sampled genera (Ancistrotermes Silvestri, 1912; Macrotermes Holmgren, 1909, Microtermes Wasmann, 
1902 and Odontotermes Holmgren, 1910) but also a higher number of species (9). Termitinae was the second most important subfamily in terms of the recorded number of genera (Amitermes Silvestri, 1901; Eremotermes Silvestri, 1911; Microcerotermes Silvestri, 1901) and also in term of sampled species (9). The other subfamilies (Apicotermitinae, Cubitermitinae, and Nasutitermitinae) were all represented by two genera except the Coptoterminiane subfamily, for which only Coptotermes intermedius Silvestri, 1912 was recorded.

Microtermes grassei Ghidini, 1955 was the most sampled species with $25.42 \%$ of occurrence (Table 1). It was followed respectively by, Microtermes toumodiensis Grassé 1937 (11.62\%), Trinervitermes oeconomus Trägårdh, 1904 (11.62\%), Microcerotermes sp (6.78\%) and Fulleritermes tenebricus Silvestri, 1914 (5.33\%). Besides these frequently sampled species, several species, including Amitermes sp. (0.48\%), Coptotermes intermedius Silvestry, 1912 (0.48\%), Odontotermes sp. 1 (0.48\%)and Trinervitermes togoensis Sjöstedt, 1899 (0.48\%), were rarely found during our study. That represented precisely the double of the total occurrence $(0.24 \%)$ of the less sampled species, Amitermes spinifer Silvestri, 1914, Ancistrotermes crucifer Sjöstedt, 1897, Cubitermes sp. and Noditermes sp. (Table 1).

\section{Newly sampled species}

Among the sampled specimens, 9 species to our knowledge were identified for the first time in Togo (showed in Table 1 with an asterisk). Two species, Amitermes sp., Eremotermes sp. could be new (not yet described) species for sciences.

\section{Feeding groups}

The sampled termite species (from both landscapes) belong to 3 out of 4 feeding groups: feeding group I (FG I), feeding group II (FG II), and feeding group IV (FG IV) (Table 1). FGI was represented by the unique species of Coptotermes intermedius, a wood-feeding termite. FG II consisted of Macrotermitinae, Termitinae, and Nasutitermitinae subfamilies, the most important feeding group with 8 genera and 21 species out of 28. Species of this group essentially feed on wood and or litter and grasses (Trinervitermes species). The last feeding group (FG IV) found in our study included 2 subfamilies Apicotermitinae and Cubitermitinae, with 4 genera: Adaiphrotermes Sands, 1972; Aderitotermes Sands, 1972 (both belonging to Apicotermitinae subfamily), Cubitermes Wasmann, 1906 and Noditermes Sjöstedt, 1924 (both genera of Cubitermitinae subfamily).

\section{Diversity analysis}

The Simpson index (1-D) for sampled termites was 0.89 (Suppl. material 1). This value is close to 1 (the highest possible value), indicating a great diversity. The same pattern of great diversity was also shown by Shannon index 2.63. 
Table I. List of termites' species collected, feeding group and habits, and relative abundance (RA).

\begin{tabular}{|c|c|c|c|c|}
\hline Feeding group & Feeding habit & Subfamilies & Termites species & RA (\%) \\
\hline \multirow[t]{2}{*}{ Group IV } & $S$ & Apicotermitinae & Adaiphrotermes sp. & 2.91 \\
\hline & & & Aderitotermes sp. & 2.66 \\
\hline Group I & W & Coptotermitinae & Coptotermes intermedius Silvestri, 1912 & 0.48 \\
\hline \multirow[t]{3}{*}{ Group IV } & $S$ & Cubitermitinae & Cubitermes sp.* & 0.24 \\
\hline & & & Noditermes cristifrons* Wasmann, 1911 & 0.73 \\
\hline & & & Noditermes sp. & 0.24 \\
\hline \multirow[t]{9}{*}{ Group II } & $\mathrm{W} / \mathrm{L}(\mathrm{F})$ & Macrotermitinae & Ancistrotermes cavithorax Sjöstedt, 1899 & 0.73 \\
\hline & & & Ancistrotermes crucifer Sjöstedt, 1897 & 0.24 \\
\hline & & & Macrotermes bellicosus Smeathman, 1781 & 1.21 \\
\hline & & & Microtermes grassei Ghidini, 1955 & 25.42 \\
\hline & & & Microtermes hollandei* Grassé, 1937 & 1.69 \\
\hline & & & Microtermes Lepidus Sjöstedt, 1924 & 3.15 \\
\hline & & & Microtermes toumodiensis* Grassé, 1937 & 11.62 \\
\hline & & & Odontotermes erraticus Grassé, 1947 & 0.73 \\
\hline & & & Odontotermes sp. & 0.48 \\
\hline \multirow[t]{5}{*}{ Group II } & W & Termitinae & Amitermes evuncifer Silvestri, 1912 & 3.15 \\
\hline & & & Amitermes guineensis Sands, 1992 & 0.97 \\
\hline & & & Amitermes sp.* & 0.48 \\
\hline & & & Amitermes spinifer* Silvestri, 1914 & 0.24 \\
\hline & & & Amitermes truncatidens ${ }^{*}$ Sands, 1959 & 1.21 \\
\hline Group IV & $S$ & & Eremotermes sp.* & 2.91 \\
\hline \multirow[t]{3}{*}{ Group II } & W & & Microcerotermes parvulus Sjöstedt, 1911 & 5.33 \\
\hline & & & Microcerotermes solidus* Silvestri, 1912 & 4.12 \\
\hline & & & Microcerotermes sp. & 6.78 \\
\hline \multirow[t]{4}{*}{ Group II } & W & Nasutitermitinae & Fulleritermes tenebricus Silvestri, 1914 & 5.33 \\
\hline & & & Trinervitermes occidentalis Sjöstedt, 1904 & 4.84 \\
\hline & & & Trinervitermes oeconomus Trägårdh, 1904 & 11.62 \\
\hline & & & Trinervitermes togoensis Sjöstedt, 1899 & 0.48 \\
\hline
\end{tabular}

S: soil feeders, W wood feeders, W/L Wood and or litter feeders, (F): fungus-growing termites, G: Grass feeders. Newly recorded species names are followed by an asterisk $\left({ }^{*}\right)$.

\section{Correlation between species richness and soil organic material}

The total organic material of soil was positively correlated with the species richness found in this landscape (Fig. 3, Suppl. material 1). The Kendall $\tau$ test $(\tau=1)$ showed that this correlation was very significant $(\mathrm{p}<0.001, \mathrm{~N}=3)$. There was also a strong, positive correlation (Fig. 4) between species richness and its total organic carbon $(\tau=1$, $\mathrm{N}=3, \mathrm{p}<0.001)$.

\section{Discussion}

\section{Diversity}

The distribution of termites (like many other terrestrial arthropods) is driven by several factors, including soil richness (Park et al. 1994; Bourguignon et al. 2015), vegetation (Park et al. 1994; Gillison et al. 2003), and also the degree of anthropogenic disturbance (Hausberger and Korb 2016; Netshifhefhe et al. 2019). In our study, the 


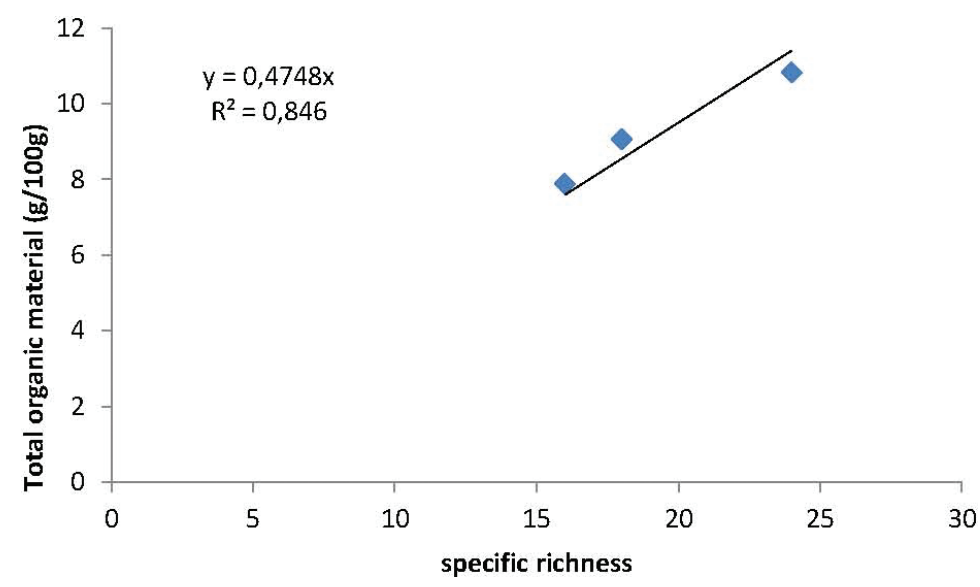

Figure 3. Correlation between species richness and total organic material (Shrub savanna).

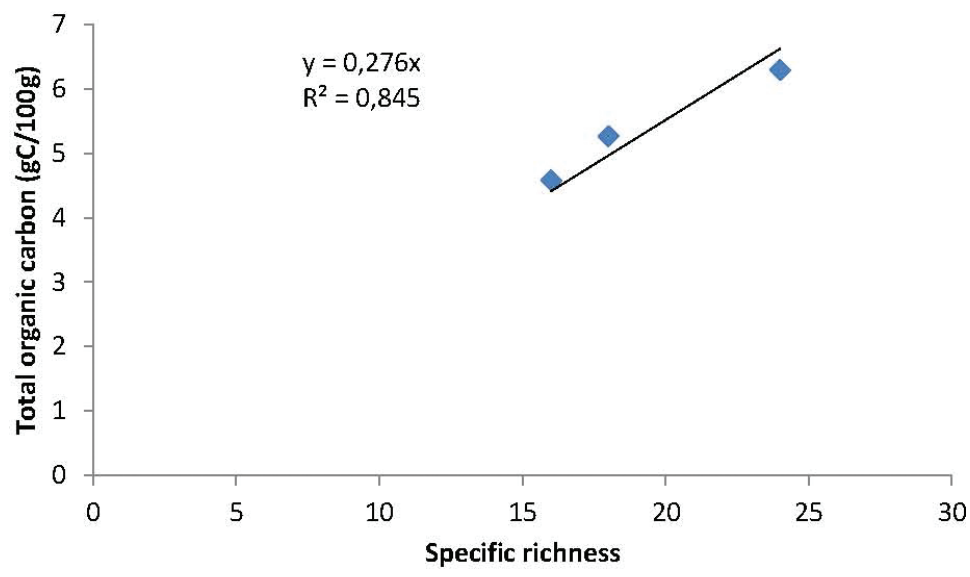

Figure 4. Correlation between species richness and total organic carbon.

main factors examined were the soil richness in organic matter and its total organic carbon. The computed diversity indices (Simpson 1-D close to 1, and Shannon over 2.5) showed that the study area was quite well diversified. Macrotermitinae subfamily, with 4 genera and 9 species, was by far the most important subfamily. Dosso et al. (2013) and Kaiser et al. (2015) carried out a similar study throughout several habitats, including semi-arid, semi-deciduous forest, food crop fields, fallow, and several agroecosystems. They found that fungus-growing termites were relatively more abundant in all their studied habitats.

\section{Feeding groups}

The high percentage of Macrotermitinae species occurrences is certainly due to their feeding habit and, therefore, to their feeding group. Indeed, these species could feed on 
diverse sources of celluloses from dry herbs to dry wood as well as dry leaves, twigs, litter, and even animal dung (Freymann et al. 2008). All these cellulose resources can be found in several landscapes. Besides the ability to feed on large cellulose resources, Macrotermitinae species also developed a symbiosis with a basidiomycete fungus, Termitomyces, which contribute to the successful decomposition of lignocelluloses (Ohkuma 2003).

Coptotermes intermedius, feed essentially on wood (dry or still alive). The presence of many kinds of wood has facilitated its occurrence in the shrub savanna. Indeed, wood feeders were reported to be very sensitive to disturbance and therefore were less abundant in habitats with few and small trees (Dosso et al. 2013). Similarly, Fulleritermes tenebricus is also found in medium to densely shrub savanna as well as a forest ecosystem (Schyra et al. 2019).

Microtermes grasse $i$ was the most sampled species indicating its ubiquitous state and its ability to dwell on large food sources. This species was also sampled in the forest ecosystem (Schyra et al. 2019) as well as in the open grassy area of a botanical garden in the middle of a city (Kasseney et al. 2019).

\section{Effect of soil organic matter on termite species richness}

A positive correlation was found between termite species richness and soil organic matter. Indeed, this landscape, as mentioned above, was a protected area since its creation. Fallen leaves, dry twigs, and branches from sampled trees are food for many termite species that recycle these plant parts (Ohkuma 2003; Brune and Ohkuma 2010). This recycling increases the amount of soil organic matter, which is beneficial for soil-dwelling termites such as Noditermes species.

\section{Newly recorded species}

The occurrences of newly recorded species underlined the importance and the contribution of this study to the knowledge of termite species in the country, in keeping with previous studies (Anani Kotoklo et al. 2011; Kasseney et al. 2019; Schyra et al. 2019). Indeed 9 out of 28 termite species were recorded for the first time in the country. Moreover, besides enlarging the country's termites list, this study, with two potentially new species (Amitermes sp. and Eremotermes sp.), appeared to be a modest contribution to termites' systematic and taxonomy throughout the entire world. Amitermes species are commonly found in arid zones as well as in wet areas (Sands 1992). The new record of these species in our study is due to the lack of available data on termites in this area. This study was the first on termites during the post-colonial period in this area to the best of our knowledge. The species of the genus Eremotermes were thought to occur exclusively in arid zones. Its presence in our study area (a Sudanian savanna) support the result of Ndiaye (2014) who sampled some species of Eremotermes in a relatively wet savanna in Senegal. Eremotermes species are very cryptic (Sarr 1999; Diop et al. 2013); for this reason they are usually not seen and sampled by the collectors in the field. 


\section{Conclusion}

It is the first recent study carried out on termites in the area mentioned above. The study area was quite well diversified. Twenty-eight (28) termite species were identified from the three sets of three transects. Macrotermitinae was the most important subfamily and Microtermes grassei was the most sampled species among them all. This study was a modest contribution to the list of termites in Togo as 9 new species (among the 28 identified) were added to the list of termites' species that occur in the country. Two of these newly recorded species (Amitermes sp and Eremotermes sp) seemed to have been hitherto undescribed to the best of our knowledge. Termites' species richness was correlated with soil organic matter.

\section{Acknowledgements}

The authors are grateful to Danpanpkergou and Mango's local villagers for their assistance and help in the field sampling. We also thank the authorities of the "Direction regional de l'Environnement de la Region des Savannes" for the logistics and other facilities. This study was part of a project financed by UEMOA (Union Economique et Monétaire Ouest Africaine).

\section{References}

Anani Kotoklo E, Amévoin K, Robert A, Tano Y, Rouland-Lefèvre C, Glitho IA (2011) Dégâts causés par les termites sur les cannes à sucre au sud du Togo. Cameroon Journal of Biological and Biochemical Sciences 19: 1-10.

Bignell DE, Eggleton P (2000) Termites in ecosystems. In: Abe T, Bignell DE, Higashi M (Eds) Termites: Evolution, Sociality, Symbioses, Ecology. Kluwer Academic Publishers, Dordrecht, 363-387. https://doi.org/10.1007/978-94-017-3223-9_17

Bouillon A, Mathot G (1965) Quel est ce termite africain? Zooleo 1: 1-115.

Bourguignon T, Drouet T, Šobotník J, Hanus R, Roisin Y (2015) Influence of soil properties on soldierless Termite Distribution. PLoS ONE 10(8): e0135341. https://doi.org/10.1371/ journal.pone. 0135341

Brune A, Ohkuma M (2010) Role of the termite gut microbiota in symbiotic digestion. In: Bignell D, Roisin Y, Lo N (Eds) Biology of Termites: a Modern Synthesis. Springer, Dordrecht, 439-475. https://doi.org/10.1007/978-90-481-3977-4_16

Collins NM (1989) Termites. In: Lieth H, Werger MJA (Eds) Tropical rain forest ecosystems. Biogeographical and ecological studies. Elsvier, Amsterdam, 455-471. https://doi. org/10.1016/B978-0-444-42755-7.50032-8

Diop A, Ndiaye AB, Ba CT (2013) Décompositions de la bouse de bovin sèche et macrofaune associée en zone sahélienne semi-aride (Matam, Sénégal). International Journal of Biological and Chemical Sciences 7(1): 147-162. https://doi.org/10.4314/ijbcs.v7i1.12 
Donovan SE, Eggleton P, Bignell DE (2001) Gut content analysis and a new feeding group classification of termites. Ecological Entomology 26(4): 356-366. https://doi.org/10.1046/ j.1365-2311.2001.00342.x

Dosso K, Konaté S, Aïdara D, Linsenmair KE (2010) Termite diversity and abundance across fireinduced habitat variability in a tropical moist savanna (Lamto, central Côte d'Ivoire). Journal of Tropical Ecology 26(3): 323-334. https://doi.org/10.1017/S0266467410000015

Dosso K, Yéo K, Konaté S, Linsenmair KE (2012) Importance of protected areas for biodiversity conservation in central Côte d'Ivoire: Comparison of termite assemblages between two neighbouring areas under differing levels of disturbance. Journal of Insect Science 12(1): e131. https://doi.org/10.1673/031.012.13101

Dosso K, Deligne J, Yéo K, Konaté S, Linsenmair KE (2013) Changes in the termite assemblage across a sequence of land-use systems in the rural area around Lamto Reserve in Central Côte d'Ivoire. Journal of Insect Conservation 17(5): 1047-1057. https://doi.org/10.1007/ s10841-013-9588-2

Dosso K, Roisin Y, Tiho S, Konaté S, Yéo K (2017) Short-term changes in the structure of termite assemblages associated with slash-and-burn agriculture in Côte d'Ivoire. Biotropica 49(6): 856-861. https://doi.org/10.1111/btp.12471

Eggleton P (2000) Global patterns of termite diversity. In: Abe T, Bignell DE, Higashi M (Eds) Termites: Evolution, sociality, symbioses, ecology. Kluwer Academic Publishers, Dordrecht, 941-960. https://doi.org/10.1007/978-94-017-3223-9_2

Freymann BP, Buitenwerf R, Desouza O, Olff H (2008) The importance of termites (Isoptera) for the recycling of herbivore dung in tropical ecosystems: a review. European Journal of Entomology 105(2): 165-173. https://doi.org/10.14411/eje.2008.025

Gillison A (2003) Vegetation indicates diversity of soil macroinvertebrates: a case study with termites along a land-use intensification gradient in lowland Sumatra. Organisms Diversity \& Evolution 3(2): 111-126. https://doi.org/10.1078/1439-6092-00072

Grassé PP (1937) Recherches pour la systématique et la biologie des termites de l'Afrique occidentale française, première partie. Annales de la Société Entomologique de France CVI: 1-100.

Green RE, Cornell SJ, Scharlemann JPW, Balmford A (2005) Farming and the fate of wild nature. Science 307(5709): 550-555. https://doi.org/10.1126/science.1106049

Hammer $\varnothing$, Harper DAT, Ryan PD (2001) PAST: Paleontological statistics software package for education and data analysis. Paleontological Electronic 4: 1-9.

Hausberger B, Korb J (2016) The Impact of Anthropogenic Disturbance on Assembly Patterns of Termite Communities. Biotropica 48(3): 356-364. https://doi.org/10.1111/btp.12278

Hausberger B, Kimpel D, van Neer A, Korb J (2011) Uncovering cryptic species diversity of a community in a West African Savanna. Molecular Phylogenetics and Evolution 61(3): 964-969. https://doi.org/10.1016/j.ympev.2011.08.015

Jones DT, Eggleton P (2000) Sampling termite assemblages in tropical forests: Testing a rapid biodiversity assessment protocol. Journal of Applied Ecology 37(1): 191-203. https://doi. org/10.1046/j.1365-2664.2000.00464.x

Jones DT, Eggleton P (2011) Global Biogeography of Termites: A Compilation of Sources. In: Bignell D, Roisin Y, Lo N (Eds) Biology of Termites: a Modern Synthesis. Springer, Dordrecht, 477-498. https://doi.org/10.1007/978-90-481-3977-4_17 
Jones CG, Lawton JH, Shachak M (1994) Organisms as ecosystem engineers. In: Samson FB, Knopf FL (Eds) Ecosystem Management. Springer, New York, 130-147. https://doi. org/10.1007/978-1-4612-4018-1_14

Kaiser D, Sylvain TBC, Yeo K, Konate S, Linsenmair KE (2015) Species richness of termites (Blattoidea: Termitoidae) and ants (Hymenoptera: Formicidae) along disturbance gradients in semi-arid Burkina Faso (West Africa). Bonn zoological. Bulletin 64(1): 16-31.

Kasseney BD, N'tie TB, Nuto Y, Wouter D, Yeo K, Glitho IA (2019) Diversity of Ants and Termites of the Botanical Garden of the University of Lomé, Togo. Insects 10(7): e218. https://doi.org/10.3390/insects10070218

Konaté S, Le Roux X, Verdier D, Lepage M (2003) Effect of underground fungus growing termites on carbon dioxide emission at the point and landscape scales in an African savanna. Functional Ecology 17(3): 305-314. https://doi.org/10.1046/j.1365-2435.2003.00727.x

Krishna K, Grimaldi DA, Krishna V, Engel MS (2013) Treatise on the Isoptera of the World. Bulletin of the American Museum of Natural History 377(7): 1-200. https://doi. org/10.1206/377.1

Lobry de Bruyn LAL, Conacher AJ (1990) The role of termites and ants in soil modification - a review. Soil Research (Collingwood, Vic.) 28: 55-93. https://doi.org/10.1071/SR9900055

Ndiaye AB (2014) Contribution à la connaissance des termites (Isoptera Brullé, 1832) du Sénégal: Systématique et Ecologie. Thèse de doctorat ès- sciences, Université Cheikh Anta Diop de Dakar, Faculté des Sciences et Techniques, 257 pp.

Netshifhefhe SR, Kunjeku EC, Duncan FD (2019) Effects of different land use patterns on seasonal termite species diversity within the Vhembe district of the Limpopo province, South Africa. International Journal of Tropical Insect Science 40: 293-307. https://doi. org/10.1007/s42690-019-00081-y

Ohkuma M (2003) Termite symbiotic systems: Efficient bio-recycling of lignocellulose. Applied Microbiology and Biotechnology 61(1): 1-9. https://doi.org/10.1007/s00253-0021189-z

Park HC, Majer JD, Hobbs RJ (1994) Influence of vegetation and soil types on the wheat belt termite, Drepanotermes tamminensis (Hill), in the Western Australian wheatbelt. Ecological Research 9(2): 151-158. https://doi.org/10.1007/BF02347490

Ruelle JE (1970) Revision of Termites of the genus Macrotermes from the Ethiopian region (Isoptera: Termitidae). Bulletin of the British Museum (Natural History). Entomology 24(9): 363-444. https://doi.org/10.5962/bhl.part.1525

Samb T, Ndiaye AB, Diarra K (2011) Biodiversity of Termites in Relation to Human Activity: Impact on the Environment in Matam (Senegal). Research Journal of Pharmaceutical, Biological and Chemical Sciences 2(1): 313-323.

Sands WA (1965) A revision of the Termites subfamily Nasutitermitinae (Isoptera): Termitidae from the Ethiopian region. Bulletin of the British Museum (Natural History). Entomology 4: $1-172$.

Sands WA (1992) The Termites Genus Amitermes in Africa and the Middle East. Natural Resources Institute Bulletin 51, 147 pp. 
Sarr M (1999) Étude écologique des peuplements de Termites dans les jachères et dans les cultures en zone soudano-sahélienne, au Sénégal. Thèse de doctorat de 3ème cycle de Biologie animale, Université Ch. A. Diop de Dakar, 117 pp.

Schyra J, Korb J (2019) Termite Communities along A Disturbance Gradient in a West African Savanna. Insects 10(1): 1-17. https://doi.org/10.3390/insects10010017

Schyra J, Gbenyedji JNBK, Korb J (2019) A comparison of termite assemblages from West African savannah and forest ecosystems using morphological and molecular markers. PLoS ONE 14(6): e0216986. https://doi.org/10.1371/journal.pone.0216986

Sileshi GW, Arshad MA, Konaté S, Nkunika POY (2010) Termite-induced heterogeneity in African savanna vegetation: Mechanisms and patterns. Journal of Vegetation Science 21(5): 923-937. https://doi.org/10.1111/j.1654-1103.2010.01197.x

Silvestri F (1912) Termitidi raccolti da L. Fea alla Guinea Portoghese e alla Isole S. Thomé, Annobon, Principe e Fernando Poo. Annali del Museo Civico di Storia Naturale di Genova 45: 211-255.

Viana JAB, Souza VB, Reis YT, Marques-Costa AP (2016) Termite assemblages in dry tropical forests of Northeastern Brazil: Are termites bioindicators of environmental disturbances? Sociobiology 61: 324-331. https://doi.org/10.13102/sociobiology.v61i3.324-331

\section{Supplementary material I}

\section{Tables S1, S2}

Authors: Toblie Quashie Effowe, Boris Dodji Kasseney, Abdoulaye Baïla Ndiaye, Bassan Banibea Sanbena, Komina Amevoin, Isabelle Adolé Glitho

Data type: diversity data

Explanation note: Table S1. Termites diversity index in the two habitats. Table S2. Correlation with Kendall $\tau$ test.

Copyright notice: This dataset is made available under the Open Database License (http://opendatacommons.org/licenses/odbl/1.0/). The Open Database License $(\mathrm{ODbL})$ is a license agreement intended to allow users to freely share, modify, and use this Dataset while maintaining this same freedom for others, provided that the original source and author(s) are credited.

Link: https://doi.org/10.3897/natureconservation.43.59474.suppl1 